\title{
China's Rise in Latin America
}

\author{
Ana Lucía Salinas de Dosch \& Jörn Dosch
}

\begin{abstract}
In November 2004 Chinese President Hu Jintao's first tour of Latin America marked the beginning of a new phase in Beijing's relationship with the region. Since then China has followed a three-fold political and economic strategy towards Latin America: first, to secure the provision of oil, minerals and agricultural products; second, to create access to new markets for the country's growing export volume of manufactured products; and third to make sure that Latin American governments adhere to the 'one China principle' in their foreign relations. This is of particular importance vis-à-vis Latin America where China had previously lost diplomatic ground when some states officially recognised Taiwan. The article asks as to whether and what extent China and Latin America countries have become economic and strategic partners. Do Latin American governments play the China card to hedge against Washington? Special emphasis is given to the case of Ecuador which exemplifies the PRC's growing prominence as an actor in Latin America. When Chinese foreign policy makers began to show some interest in Latin America during the early 1960s Ecuador was not a priority. However, the PRC has significantly strengthened its interests towards, and presence in, Ecuador since 2005. The provision of oil but also metals primarily copper and cold - and increasingly agricultural products has taken centre-stage in Beijing's strategy towards the Andean country. The article argues that while China's influence in Latin America has undoubtedly increased significantly during the last halfdecade, its role is still overshadowed by the US.
\end{abstract}

Keywords: China, Latin America, Ecuador, United States, Beijing Consensus, oil, minerals.

\section{Introduction}

Conceptualising and explaining China's rise - and particularly Beijing's hunger for raw materials and resources - has been engaging academics and policymakers for some time. Interestingly, to date the vast majority of observers have focused on the PRC's growing economic and political involvement in sub-Saharan Africa, in addition to ever-tightening relations between Beijing and its regional neighbours in East Asia. China's emergence as an important actor in Latin America has attracted relatively little scholarly attention. This is surprising given the substantial intensification of Chinese-Latin American interaction, especially since November 2004, when Chinese President Hu Jintao's first tour of Latin America marked the beginning of a new phase in Beijing's relationship with the Western 
hemisphere. China's trade with the region totalled 180 billion USD in 2010, up 50 percent from 2009 and evincing a sharp growth since 2000, when the China-Latin America trade volume stood at just 13 billion USD. By 2007 bilateral trade had already exceeded Hu's original benchmark of 100 billion USD, set for 2010 (China Daily, 13 June 2011).

On the other hand, trade is only one of several aspects of the PRC's relations with Latin American states. The frantic, and in most cases successful, attempts of Chinese state-owned corporations (such as Petro China and Sinopec) to get their hands on Latin American oil and other commodities; the establishment of "strategic partnerships" and "strategic dialogues" with several states in the region; China's training of increasing numbers of Latin American military personnel; extensive party-to-party ties of the Chinese Communist Party (CCP) with political parties across the continent; and other examples of the intensifying Sino-Latin American links seemingly support the neorealist notion of China following a "containment through surrogates" strategy (Malik, 2006). According to this view, Beijing counters the perceived containment of its regional and global aspirations by the United States (and its allies) and engages in soft-balancing of the OECD world through trade, investment, development aid and an increasingly active role in multilateral settings. The PRC is a founding member of the Forum for East Asia-Latin America Cooperation (FEALAC), a permanent observer at the Organization of American States (OAS) and has expanded its diplomatic ties to the Group of Rio, the Andean Community, and the Caribbean Community (CARICOM). China, so the argument goes, is taking advantage of a power vacuum in the region that was created by the United States' and Russia's declining interest in Latin America (Li He, 2008, p. 195).

Jilberto and Hogenboom (2010: 191) see clear parallels in the Chinese and Latin American approaches to economic development: "As a result of many leftist governments in Latin America, an interesting pragmatic convergence with China has come about: The state is granted an important role in the economy (again) [....] China and Latin America have both been moving in the direction of a development model in which there is reconciliation of state and market". Have China and Latin America become natural bedfellows? Is the so-called Beijing Consensus replacing the Washington Consensus? ${ }^{1}$ Do Latin American governments play the China card to hedge against Washington? How does involvement with the PRC impact the domestic conditions in individual Latin American countries? These are some of the questions that this article addresses. It begins with a brief overview of the history of China-Latin America relations before delving into China's rise as an economic power in the region and the potential implications of this for the role of the US. Special emphasis is given to the case of Ecuador which exemplifies the PRC's growing prominence as an actor in Latin America. We argue that while China's influence in Latin America has undoubtedly increased significantly during the last half-decade, its role is still overshadowed by the US. 


\section{A Brief History of China-Latin America Relations}

The earliest contact between Latin America and Asia was the Spanish colonisation of the Philippines in the second half of the sixteenth century. The enormous increase in output of the silver mines in Spanish America in the 1570s began to have an effect on Asia. Some of the silver was carried directly to Manila from Acapulco and New Spain's western ports to buy Southeast Asian spices and Chinese goods that had travelled south. This sea trading route existed for more than two centuries before the Spanish Pacific fleet ceased its service in 1815. According to Chinese accounts, contacts between the two continents pre-date even the Spanish empire and go back to Chinese expeditions reaching the American continent as early as the fifth century. In his bestselling book 1421: The Year China Discovered America, former British naval officer Gavin Menzies claimed the expeditions of Chinese seafarer Zheng He (1371-1433) in the first half of the fifteenth century reached as far as America and circumvented the globe. While the admiral's fleet undoubtedly visited the east coast of Africa as part of a series of seven naval expeditions sponsored by the Ming rulers, no hard evidence has ever emerged for Zheng's travels to the Western hemisphere and it does not take too much effort to deconstruct Menzie's argument and disprove the facts it is based on (Goodman, 2006).

Fast forward to the Cold War era and the ideologically motivated and balance of powerdriven encounter between East Asia and Latin America prominently associated with, first, the Non-Aligned Movement (NAM) and, second, the dynamics of Sino-American and SinoSoviet relations. While it was Argentine President Juan Domingo Perón who pioneered the principles of non-alignment and peaceful coexistence within the context of the "Third Position" ideology, Latin America never quite managed to match the influence of Asia in the NAM. Only in Fidel Castro did the continent have a protagonist rivalling the status of Nehru in India or Sukarno in Indonesia within the movement that was de facto inaugurated by the Bandung Conference in 1955 and institutionalised at the Belgrade summit meeting in 1961. But Castro was also Latin America's dilemma: The position of members from the Western hemisphere - with Bolivia, Brazil and Mexico being the most active in the early 1960s - had been made more difficult to pin down due to Cuban ambiguity about what non-alignment meant and because of Castro's refusal to renounce the advocacy of revolution (Calvert, 1994, p. 212-13). This position, in turn, and the Cuban revolution in general, opened up a window of opportunity for Mao's China. In the early 1960s, the motivation of the Chinese leadership to include Latin America in its foreign policy, albeit in a distant third position behind Asia and Africa, was mainly linked to Beijing's anti-US stance and the quest to counter Washington's economic blockade and political hostility (Xu, 1994, p. 151).

China showed great interest in Castro's rise and hoped to see the emergence of the Cuban Revolution as a model for other parts of the region. However, China's flirtation with communist parties and movements made an only very limited impression in Central and South America (Lawrance, 1975, p. 152). Once the Sino-Soviet split had escalated into full-scale political and military antagonism towards the end of the 1950s, "China began 
to discard political biases, distance itself from radical movements and guerrilla bands, and develop relations with established national governments in Latin America" in an attempt to secure more support for its international position (Xu, 1994, p. 152). There was little choice: Anti-communism prevailed for the better part of the Cold War in most Latin American states, particularly those ruled by right-wing military dictatorships, leaving Beijing little room to make diplomatic advances (Philips, 2010, p. 178-9).

The Kissinger and Nixon visits to China in 1971-72eventually paved the way for pragmatic and issues-oriented relations between Beijing and Latin American capitals, free of any ideological ballast. By the end of the decade, China had established diplomatic relations with most major Latin American states, including Argentina, Brazil, Chile, Mexico and Peru. Chinese-Latin American relations in the 1970 s and 1980 s were predominantly politically motivated and were driven by quidproquo strategies. For example, most Latin American governments voted in favour of granting China entry into the United Nations, while Beijing supported Latin American claims for 200-mile territorial sea limits in the Law of the Sea negotiations.

\section{Strategic Approaches}

A core strategic issue in this context is the Taiwan factor. The diplomatic isolation of Taiwan has been perhaps the highest-ranking key political objective for the PRC in Latin America, where Beijing and Taipei have competed fiercely with each other, mobilising extensive diplomatic and economic resources to hold their camps together (Teng, 2007, p. 102). Currently, only 23 national governments maintain diplomatic relations with Taiwan; 11 of them are in Latin America, including some small Caribbean nations. The most recent state (2007) to switch diplomatic relations from Taiwan to the PRC was Costa Rica,marking a particularly serious setback for Taipei. Central America plays a key role inTaiwan's quest for international recognition because it is one of the few regions where the country is welcome as an official member of international organisations. Taiwan is a non-regional member of the System of Central American Integration (SICA) and the Central American Bank of Economic Integration (BCIE) and was granted observer status at the Central American Parliament (Aguilera Peralta, 2010, p. 171).

In a similar vein, the PRC's strategic objectives in Latin America are directed towards fostering cooperation in the political-strategic field in order to develop joint strategies in international forums. In UN organisations, Argentina and China often share positions regarding key matters on both countries' foreign agendas. Following a quidproquo approach, Argentina has abstained from voting on the US-sponsored resolutions to investigate China's human rights situation, while the PRC has continuously supported Argentina's position on the Islas Malvinas (Falkland Islands) in the UN Committee on Decolonalisation. Furthermore, in 2005 the two governments agreed to take a common stance against the US and EU agriculture subsidies at the WTO summit in Hong Kong (Olivia, 2010, p. 105, 112). According to Henrique Altemani de Oliveira (2010), a strategic partnership between Brazil and China has emerged in the field of scientific and technological cooperation with the 
objective of breaking "the monopoly held by developed nations". In 2010, China overtook the US as Brazil's biggest trade partner with a volume of more than 56 billion USD.

\section{China's Emergence as an Economic Actor in Latin America}

Bilateral trade and investment in China's relations with most Latin American countries was insignificant until well into the 1990s. It was Japan, not China, that spearheaded the development of substantial economic links between East Asia and Latin America. The eventual failure of import substitution in Latin America and the concurrent success of East Asian economies with outward and more market-oriented policies in the 1980s and 1990s led Latin America to look to East Asia as a source of stimulation if not a model. The so-called "Asian Miracle" is even said to have contributed to Latin America's shift towards more openness in the late 1980s and throughout the 1990s (Edwards, 1995; Tussie, 2004; Kay, 2002). By the early 1990s Japan had established itself as the second-largest trade partner of most Latin American economies and Tokyo had become the largest lender to Latin America, both bilaterally and through its contributions to international financial institutions (Stallings \& Horisaka 1994, p. 126).

However, the more that other Asian states took an interest in Latin America, the weaker Japan's economic and political status became, and the country's relations with the region declined starting in the late 1990s. Japan accounted for 11.4 percent of Latin America's total trade in 1990. By 2005 this statistic was reduced to 6.5 percent, whereas other Asian countries showed a rapid increase from 7.6 percent to 22.5 percent (Rose, 2010). South Korea benefited in particular, as Asian firms were looking "for new frontiers beyond the increasingly conflictive industrial markets of the US and Europe” (Kim, 2004, p. 5).

Free Trade Agreements (FTA) have been signed between Japan and Mexico; Japan and Peru; Chile and Korea; and Peru and Thailand, respectively; a Preferential Trade Agreement (PTA) has come into effect between India and MERCOSUR (Common Market of the Cono Sur, grouping Argentina, Brazil, Paraguay and Uruguay). A number of bilateral arrangements are also being explored between various Asian countries (Japan, Korea, and Singapore) and Latin American countries (Brazil, Chile, and Mexico). However, it was China's charm offensive of the early twenty-first century - which saw an initial peak with President $\mathrm{Hu}$ Jintao's first tour of Latin America in 2004 (his visit made a much stronger impact than that of his predecessor Jiang Zemin's in 2001 visit) and increasing levels of diplomatic and economic activity - that has captured everyone's imagination. So far, China has signed three FTAs in Latin America: with Chile (in force since 2006), Peru (in force since 2010) and Costa Rica (signed in 2011).

The increase in trade has been accompanied by fast growing Chinese Foreign Direct Investment (FDI) which reached approximately 15 billion USD in Latin America and the Caribbean in 2010, representing 9 percent of the region's total FDI. ${ }^{2}$ More than 90 per cent has been invested in natural resource extraction. The main recipient countries were 
Brazil, Argentina and Peru. China has established itself as the third-largest investor in the region, behind the United States and the Netherlands. ${ }^{3}$ Until 2009, Chinese FDI had barely registered. While the US still provides the biggest percentage of FDI in the region, accounting for 17 percent of the 113 billion USD in 2010, the gap is gradually narrowing (ECLAC 2011). During Chinese Vice-President Xi Jinping's "low-key Latin American tour" of Chile, Uruguay and Cuba in June 2011 alone, several agreements were signed that not only strengthen China's access to Chilean copper and Uruguayan soy but also cemented Beijing's role in the development of Cuban oil, including Cuba's soon-to-be-explored fields in the Gulf of Mexico (Iturrieta, 2011). This is only the latest in a series of events that have not gone unnoticed by Washington. President Barack Obama's visit to Latin America in March 2011, his first trip to the region in almost two years, has widely been interpreted as an attempt to reassert economic leadership in the region that Washington has traditionally dominated. It was no coincidence that Obama used the occasion to showcase Chile, which has thrived on the "Washington Consensus".

The impact of China's investment deals on the Latin American economiesis contested. An often voiced concern is related to the region's potential long-term dependence on a small number of commodity exports. Chinese companies have secured a decade's worth of oil from Venezuela and Brazil, and significant supplies of wheat, soybeans, natural gas and iron ore from Argentina. Under a two billion USD joint venture, agreed upon in 2005, China is guaranteed 836,250 metric tonnes of Chilean copper over 15 years, at rates fixed to the (then) market price of 2.07 USD per pound. Considering that copper was trading above four USD a pound in 2011, China is getting copper at far below market prices (James, 2011). This trend towards a "primatisation" of Latin America's exports to China spells the danger of a possible return of a centre-periphery trade pattern that has been at the core of scholarly and political discourses on the region since the 1940s (Jenkins \& Dussel Peters, 2009, p. 9-10).

While the reasons behind China's economic interests towards Latin America are no mystery- the interests are mainly driven by the need for a steady, and increasing, flow of commodities and raw materials to keep China's economy growing, related political and geostrategic motives are harder to assess. June Teufel Dreyer (2006: 2) suggests that "Latin America and the Caribbean are crucial to the evolution of the world order that the Chinese leadership would like to see." Do Latin American governments concur? According to some analysts, China is already being seriously looked at as an "alternative diplomatic and economic partner to Washington" (Lanteigne, 2009, p. 139) [emphasis added]). In this context, Manfred Mols (2010) differentiates three clusters in China's bilateral relations with Latin America: strategic partners (Brazil, Mexico, Argentina, Venezuela), cooperative partners (Chile, Peru, Cuba) and friendly-cooperative partners (Central America and the Caribbean).

While Ecuador is not mentioned in any of the three categories there can be little doubt that the country has recently emerged as one of China's key partners in the Western Hemisphere. 


\section{The Case of Ecuador}

Ecuador is a fascinating test case for China's new involvement in Latin America because all of the PRC's main interests- opening of new markets, access to commodities and general geostrategic consideration which are prominently associated with the Taiwan factor - have become visible since Beijing strengthened its interests towards, and presence in, Ecuador around 2005.

Chinese retailshops and other small businesses have mushroomed all over Ecuador and become a commonsight in almost every town and city. At the same time mystery surrounds the growing Chinese presence. Local shopkeepers ask themselves: how are the Chinese competitors able, for example, to offer three times the going monthly rent of about 100 USD for a small store in the centre of Cuenca, Ecuador's third largest city? According to government estimates, a majority of Chinese businesses do not operate legally in the country. Only the largest enterprises, two oil companies and two corporations of the communications and electronics sector are registered with the Superintendencia de Compañías, the national regulative agency of the private sector. According to Xavier Patiño, Executive Director of the Chamber of Commerce in Cuenca, "the knowledge about many Chinese businesses is minimal. Among the dozens of Chinese stores in the city, only five or six are members of the Chamber (author interview in Cuenca, August 2007).

Many Ecuadorian stakeholders are convinced that Chinese shopkeepers received some form of subsidies from the Chinese government to set up their businesses and successfully compete against national enterprises. However, it is impossible to find hard evidence for this claim as the Chinese entrepreneurs are usually tight lipped about their businesses. Yet, it is undisputed that China needs markets for its electronics, apparel, toys, textiles and footwear. Between 2004 and 2010 China's total trade with Ecuador grew 5.5 times from 436 million USD to 2.4 billion USD in 2010 - mainly due to rapidly increasing Chinese exports to the Andean country (Xinhua Economic News Service, 13 August 2008). While the volume of Ecuador's exports to China is still small, it has been growing too. According to the Chinese Ministry of Commerce, Ecuador has already emerged as one of China's major trade partners in South America. In November 2010, Quito and Beijing signed a 20 million USD procurement agreement to support agricultural exports, including banana and fish meal and flour, from Ecuador, which will now supply eight Chinese companies regularly (China Knowledge Newswires, 2010; Renuncio Mateos, 2010). Other Chinese firms have indicated strong interest in importing coffee and fruits from Ecuador.

Growing trade, however, is only secondary to China's quest for access to Ecuadorian oil. Ecuador, the smallest of the OPEC members in terms of crude output, has 6.03 billion barrels of proven oil reserves - the third largest reserve in Latin America, just after Venezuela and Brazil. Ecuador pumped about 486,000 barrels per day in 2010, of which 62 percent were moved by the state owned enterprise Petroecuador and the rest by foreign firms. Of its output, Ecuador exports about 340,000 barrels per day and generated revenues of 8.93 
billion USD in 2010 (Agence France Presse, 23 February 2011). In 2005, a joint venture of the Chinese petroleum companies agreed to buy the Canadian EnCana Corporation's oil and pipeline assets in Ecuador for 1.42 billion USD. Since 2007 Andes Petroleum, which is owned by two Chinese state companies (China National Petroleum Corporation and Sinopec) has heavily invested in Ecuador's oil sector. Andes Petroleum produces 62,000 barrels per day, equal to 12 percent of Ecuador's total, state and private, crude oil output (Latin America News Digest, 2008).

Another core area for Chinese investments is the Ecuadorian copper industry. In 2009, a massive deposit of some 600,000 tonnes of copper was discovered in Ecuador. A venture of two Chinese firms plans to invest three billion USD in the Corriente Copper Belt. Production is likely to start in 2013 with an expected output of 30,000 tons in the first year which is projected to double a year later (Tendersinfo 14 August 2010, 24 September). China's own copper resources are insufficient to keep up with its rapidly growing economy. There is a major bottleneck though: improvements to Ecuador's transport infrastructure are crucial for Chinese investments and generally FDI to take full effect.

In line with the global trend in China's foreign economic relations, Chinese investment in Ecuador has been accompanied by development aid. In 2006, the Chinese government for the first time extended two loans of 2.4 million USD to Ecuador. And in February 2009, China and Ecuador signed four cooperation agreements totalling 25 million USD. As part of the agreements China granted a credit line to Ecuador of about 7.3 million USD to increase trade in agricultural products and investment in the country's agricultural sector (Business Daily Update, 2009). Other assistance provides computer technology and supports higher education in Ecuador. In late December 2010, the first Confucius Institute opened its doors in Ecuador to promote Chinese language and culture - at San Francisco University in Quito. Furthermore in May 2006, China added Ecuador to the list of approved overseas tourism destinations for Chinese citizens. In return - and on various other occasions - the Ecuadorian government has reaffirmed its one-China policy and support of China's position on the Taiwan question. According to the Chinese Ministry of Foreign Affairs, "the two countries maintained sound cooperation in the United Nations and other international and regional organizations. The government of Ecuador is committed to the one China position on issues related to Taiwan and Tibet (Ministry of Foreign Affairs of the PRC, 2010).

\section{The China-Latin America-US Triangle}

China's open flirtation with its strategic partners like Ecuador, both in terms of political and economic relations, has the potential to challenge the United States. But so far China has not been interested in fully exploiting the potential that having closer relations with the socialist, left-wing regimes - particularly that of Venezuela but also Bolivia and Ecuadormight have in terms of diminishing US power in the region. "China tacitly acquiesces to the Monroe Doctrine” (Camarena, 2010, p. 47). Beijing's rejection of Hugo Chávez's advances is a case in point. Despite Chávez's high-profile visit to China in 2006, the fact that about 
20 percent of Venezuela's oil exports are destined for China, and since Beijing announced that it would provide more than 32 billion US Din loans to the government in Caracas, the PRC has been reluctant to hop onto the Venezuelan bandwagon of anti-American rhetoric.

Obama's Latin America tour of 2011 cannot cover for that fact that the Chinese presence in Latin America is not a high priority for Washington; China's relations with the region have remained a minor issue because they lack sufficient strategic and political importance for the United States. Washington's perception might change soon, though, as there are already a number of factors that it is starting to become concerned about. The US is mostly interested in supporting liberal and economic orders and deepening economic integration between itself and Latin American countries. With regard to these core interests, the US is closely observing Sino-Latin American relations to understand whether China is disrupting the existing patterns of bi- and multilateralism. For the time being, however, China pursues pragmatic policies in Latin America.

Overall, there can be little doubt that some governments perceive a partnership with Beijing as a welcome means of soft-balancing or hedging against traditional US hegemony in the region. While Latin American governments may rightly complain about a frequent lack of serious attention on the part of the United States and the latter's rather narrowly defined national security interests in its relations with its hemispheric neighbours, why should they be interested in replacing a decades-long dependency on the United States by a new dependency on China? Is there any convincing economic reason for Latin American countries to play the China card in an attempt to balance against the United States? China is an increasingly important factor in Latin America, but it is one among many. David Shambaugh (2008) accurately stresses that Latin American countries "embrace China as part of their new multidirectional diplomacy". Multidirectional is the key word here. All Latin American governments have diversified their foreign relations. Their main interest is moderating US hegemony, not substituting it. As part of this strategy and particularly in times of economic hardship such as in the wake of the global economic crisis of 2008-09, every trade and investment opportunity is welcome. States in the era of globalisation are best described as rational opportunity maximisers. This applies to Latin America as much as to East Asia; it is true for Vietnam or South Korea in the same way as Peru or Mexico. The result of opportunity-maximising in Asia-Latin America relations is a growing trans-Pacific network comprising trade, investment, political and even security links in both bilateral and (increasingly) multilateral contexts.

\section{Conclusion}

China follows a three-fold political and economic strategy towards Latin America: first, and most importantly, to secure the provision of oil, minerals and agricultural products; second, to create access to new markets for the country's growing export volume of manufactured products; and third to make sure that Latin American governments adhere to the 'one China principle' in their foreign relations. This is of particular importance vis-à-vis Latin America 
where China had previously lost diplomatic ground when some states officially recognised Taiwan.

Overall, China is an increasingly important factor in Latin America but it cannot supersede the role of the United States. US trade and investment in Latin America is not only much larger than that of China, but Washington's economic engagement has so far also been qualitatively different from that of China - as a provider of high tech and knowledge-based goods and services. However, this might be changing in the years to come when the majority of the Latin American countries are likely to have made more progress towards diversifying its foreign relations. In this process the main interest is directed at moderating US preeminence, not substituting it. This also implies that any open embrace of the so-called Beijing Consensus in Latin America seems unlikely. While it is true that China and many Latin American governments subscribe to a development model in which the reconciliation of the state and the market is key, and both broadly confine to what has been labelled the Beijing Consensus, the similarities do not go beyond a pragmatic convergence of economic interest in the broadest sense. China is not attractive a model for governance due to the strong rejection of even the slightest hint at authoritarianism across most parts of Latin America.

\section{End Notes}

1 The term "Beijing Consensus" is not an invention of the Chinese government or Chinese scholars but was coined in 2004 by the consultant Joshua Cooper Ramo in paper entitled The Beijing Consensus for the UK based Think Tank Foreign Policy Centre which was launched under the patronage of the then British Prime Minister Tony Blair.

2 The FDI figures provided by ECLAC are much lower than in other reports because they exclude large sums of FDI in the region reportedly are destined for off-shore financial havens (such as the Cayman Islands and the Virgin Islands), which are then to be reinvested in China (thereby taking advantage of tax breaks for "foreign companies"). For example, according to PRC official data, Latin Amerika had received 22 billion USD in cumulative PRC investment by the end of 2006. When the tax havens were excluded, only approximately 1.9 billion USD remained (Lum et al. 2009: 12-13). Royal Dutch Shell has traditional been one of the largest investors in Latin Amerika and in 2010 the relative position of the Netherlands was further strengthened due to Heineken's acquisition of Mexico's FEMSA brewery.

3 Royal Dutch Shell has traditional been one of the largest investors in Latin America and in 2010 the relative position of the Netherlands was further strengthened due to Heineken's acquisition of Mexico's FEMSA brewery. 


\section{References}

Ecuador rings up billion-dollar oil sale to China. (2011, February 23). Agence France Presse.

Aguilera Peralta, G. (2010). Central America between Two Dragons: Relations with the Two Chinas. In A. E. Fernández Jilberto \& B. Hogenboom (Eds.), Latin America facing China. South-south relations beyond the Washington consensus (pp. 167-180). New York: Berghahn Books.

Altemani de Oliveira, H. (2010). Brazil and China: From south-south cooperation to competition? In Alex E. Fernández Jilberto \& Barbara Hogenboom (Eds.), Latin America facing China. South-south relations beyond the Washington Consensus (pp. 33-54). New York: Berghahn Books.

China signs cooperation agreements with Ecuador. (2009, February 16). Business Daily Update.

Calvert, P. (1994). The international politics of Latin America. Manchester: Manchester University Press.

Camarena, A. (2010). Poaching in the hegemon's backyard?Relations between China and Latin America and the US response. In J. Dosch \& O. Jacob (Eds.), Asia and Latin America the encounter of two continents: Political, economic and social dynamics (pp. 31-50). London: Routledge.

China, Ecuador ink cooperation agreement. (2010, 19 November). China Knowledge Newswires.

Cooper Ramo, J. (2004). The Beijing consensus. London: The Foreign Policy Centre.

Economic Commission for Latin America and the Caribbean [ECLAC]. (2011, May). Foreign Direct Investment in Latin America and the Caribbean. Santiago de Chile: ECLAC.

Edwards, S. (1995). Crisis and reform in Latin America: From despair to hope. New York: Oxford University Press.

Fernández Jilberto, A. E., \& B. Hogenboom. (2010). Latin America - from Washington Consensus to Beijing Consensus. In A. E. Fernández Jilberto \& Barbara Hogenboom (Eds.), Latin America facing China. South-south relations beyond the Washington Consensus (pp. 181-194). New York: Berghahn Books. 
Goodman, D. S. G. (2006). Mao and the Da Vinci Code: Conspiracy, narrative and history. The Pacific Review, 19(3), 359-384.

Horisaka, Kotaro. (2005). Japan and Latin America - Missing strategies and political will. In Mols, M., J. Faust, \& Woh-Ho Kim (Eds.). Latin America and East Asia-Attempts at diversification, Münster: Lit.

Iturrieta, F. (2011, June 10). China's Xi wants greater trade with Latin America. Reuters.

James, I. (2011, June 9). China pours billions into Latin America. Los Angeles Times.

Jenkins, R., \& E. Dussel Peters. (2009). Introduction. In R. Jenkins \& E. Dussel Peters (Eds.).China and Latin America. Economic relations in the twenty-first century (pp. 1-20). Bonn: German Development Institute.

Kay, C. (2002). Why East Asia overtook Latin America: Agrarian reform, industrialisation and development. Third World Quarterly, 23(6), 1073-1102.

Kim, W. H. (2004). East Asian-Latin American economic relations: A Korean Perspective after the international financial crisis. Seoul: Korean Institute for International Economic Policy (KIEP) Working Paper 00-04.

Lanteigne, M. (2009). Chinese Foreign Policy. London: Routledge.

Ecuador, China Andes Petroleum to sign contracts - report. (2008, August 25). Latin America News Digest.

Lawrance, A. (1975). China's foreign relations since 1949. London: Routledge \& Kegan Paul.

Li He. (2007). China's growing interest in Latin America and its implications. Journal of Strategic Studies, 30(4), 833-862.

Li He. (2008). Latin America and China's growing interest. In Quansheng Zhao \& Guoli Liu (Eds.). Managing the China challenge. Global Perspectives (pp. 195-214). London: Routledge.

Lum, T. et al. (2009, February 25). China's foreign aid activities in Africa, Latin America and Southeast Asia. Washington D.C.: Congressional Research Service.

Malik, Mohan. (2006, June 12). China's growing involvement in Latin America. Power and Interest News Report (PINR).

Menzies, G. (2002). 1421: The year China discovered the world. London: Bantam. 
Ministry of Foreign Affairs of the PRC. (2010). China, Ecuador move toward energy deal. Retrieved from http://www.mfa.gov

Mols, M. (2010). Is China the avant-garde of East Asia in Latin America? In J. Dosch \& O. Jacob (Eds.), Asia and Latin America the encounter of two continents: Political, economic and social dynamics (pp. 15-30). London: Routledge.

Philips, N. (2010). China and Latin America: Development challenges and geopolitical dilemmas. In L. Dittmer \& G. T. Yu (Eds.), China, the developing world, and the new global dynamic (pp. 177-202). Boulder/Col.: Lynne Rienner.

Renuncio Mateos, I. (2010, November 19). Ecuador, China sign co-operation agreements. Global Insight.

Rose, C. (2010). Japan and Latin America - Can the Koizumi effect last? In J. Dosch \& O. Jacob (Eds.), Asia and Latin America the encounter of two continents: Political, economic and social dynamics (pp. 51-69). London: Routledge.

Shambaugh, D. (2008, November 17). China's new foray into Latin America. YaleGlobal. Retrieved from http://yaleglobal.yale.edu/

Stallings, B., \& K. Horisaka. (1994). Japan and Latin America: New patterns in the 1990s. In A. F. Lowenthal \& G. F. Treverton (Eds.), Latin America in a new world (pp. 12649). Colorado: Westview Press.

China: China's revenue up 26\% in Ecuador Copper Project. (2010, August 14). Tendersinfo.

Ecuador: China to invest USD 3 billion in Ecuador copper mine. (2010, September 24). Tendersinfo.

Teng, C. C. (2007). Hegemony or partnership: China's strategy and diplomacy toward latin America. In J. Eisenman, E. Heginbotham \& D. Mitchell (Eds.), China and the developing world: Beijing's strategy for the twenty-first century (pp. 84-112). New York: M. E. Sharpe.

Teufel D. J. (2006). The China Connection. In China-Latin America Task Force MarchJune 2006. University of Miami: Center for Hemispheric Policy.

China's trade with Ecuador in May 2008. (2008, August 13). Xinhua Economic News Service.

Xu, F. (1994).China and Latin America after the cold war's end. In A. F. Lowenthal \& G. Treverton (Eds.), Latin America in a New World (pp. 150-66). Colorado: Westview Press. 
